\title{
ARTYKUtY
}

Klio. Czasopismo poświęcone dziejom Polski i powszechnym

PL ISSN 1643-8191, t. 43 (4)/2017, s. 85-105

(c) (1) $\Theta$

http://dx.doi.org/10.12775/KLIO.2017.046

Mariusz WoŁos", Ewa KLIMCZYK"*

\section{Jak to strzelcy Nabokowom Kacice rekwirowali, czyli o makrohistorii odzwierciedlonej w mikrohistorii}

\section{How did the Nabokov's Majorat Kacice Shooters recapture, that is macrohistory reflected in the microhistory}

Streszczenie: Majorat Kacice w Królestwie Polskim otrzymał od cara jako donację Dymitr Nikołajewicz Nabokow, późniejszy rosyjski minister sprawiedliwości i przedstawiciel znanej ziemiańskiej rodziny. Po nim Kacice odziedziczył syn Dymitr Dymitrowicz, ojciec słynnego kompozytora Nikolasa i stryj równie słynnego pisarza Władimira. W sierpniu 1914 roku strzelcy dowodzeni przez Józefa Piłsudskiego dokonali symbolicznej rekwizycji Kacic w imieniu nieistniejącego rządu narodowego, równie symbolicznie mszcząc się na Rosjanach za krzywdy uczynione Polsce. W majątku Polacy przeprowadzili rekwizycje

* Instytut Historii i Archiwistyki Uniwersytetu Pedagogicznego im. Komisji Edukacji Narodowej w Krakowie, ul. Podchorążych 2, 30-084 Kraków, mariusz.wolos@ gmail.com;

** Instytut Historii i Archiwistyki Uniwersytetu Pedagogicznego im. Komisji Edukacji Narodowej w Krakowie, ul. Podchorążych 2, 30-084 Kraków, ewa.zielonooka. klimczyk@gmail.com. 
koni i broni wykorzystywanych następnie do walki przeciwko armii rosyjskiej. Tekst jest studium przypadku, które posłużyło autorom do przedstawienia skomplikowanych relacji między Polakami i Rosjanami.

Abstract: Majorat Kacice in the Kingdom of Poland received a donation from the Tsar Dmitri Nikolayevich Nabokov, the later Russian Minister of Justice and a representative of a well-known landowner. After him Kacice inherited your son Dmitri Dimitrovich, father of the famous composer Nikolas and uncle of the famous writer Vladimir. In August 1914, Shooters commanded by Józef Piłsudski made a symbolic requisition of the Majorat Kacice in the name of a non-existent polish national government, symbolically mourn on the Russians for the harm done to Poland. In the estate Poles also carried requisitions of horses and weapons used to fight against the Russian army. The text is a case study that has helped authors to present intricate relationships between Poles and Russians.

Słowa kluczowe: rodzina Nabokowów; strzelcy Piłsudskiego; Kacice; mikrohistoria; makrohistoria; relacje Polaków i Rosjan; pierwsza wojna światowa

Keywords: Nabokov family; Shooters of Piłsudski; Kacice; Microhistory; Macrohistory; Relations of Poles and Russians; First World War

$\mathrm{O}$ krągłe rocznice wielkich wydarzeń historycznych, do jakich doszło przed wiekiem, skłaniają do wspomnień o przeszłości naszej ojczyzny w czasie konfliktu światowego, który współcześni całkiem zasadnie nazwali wielką wojną, biorąc pod uwagę jego skalę, liczbę ofiar i dalekosiężne konsekwencje. Od wybuchu I wojny światowej minęło z górą 100 lat, ale dla ziemi miechowskiej, położonej wówczas przy granicy imperium rosyjskiego i Austro-Węgier, wciąż jest to historia żywa, nieodległa, bo ledwie na przysłowiowe wyciągnięcie ręki. Przypominają o niej coroczne marsze szlakiem Pierwszej Kompanii Kadrowej. Przypominają także pomniki, zabytki architektury, wreszcie żołnierskie mogiły - ślady przesuwającego się po tej ziemi w pierwszych miesiącach wielkiej wojny frontu wschodniego. Granicy zaborczej na szczęście już dawno nie ma, choć granice mentalne - bodaj najtrwalsze ze wszystkich - w takim czy innym kształcie wciąż istnieją. Na zachodnich krańcach imperium Romanowów mieszkali przed 100 laty nie tylko Polacy i Żydzi. Byli tutaj również Rosjanie. I nie chodzi w tym przypadku o przysłanych ze wschodu na państwową służbę urzędników, nauczycieli, policmajstrów, żandarmów czy pograniczników. Wśród 
zamieszkujących ziemię miechowską Rosjan nie brakowało reprezentantów znamienitych rodów żyjących przez dziesięciolecia wśród Polaków, aczkolwiek nie zawsze potrafiących nawiązać z nimi dobrosąsiedzkie kontakty. Zbyt wielkie były bowiem między nimi historyczne, polityczne, religijne oraz mentalne bariery, na które po raz wtóry kładziemy akcent, bo są one wdzięcznym i interesującym polem badań nie tylko dla historyków. Jednej $\mathrm{z}$ takich rodzin poświęcamy ten tekst.

W naszych rozważaniach wkraczamy w skomplikowane, a kształtowane przez wieki relacje polsko-rosyjskie, w przypadku których po obu stronach padają nader często oskarżenia o ruso- lub polonofobię. Nie chodzi bynajmniej wyłącznie o międzynarodowy czy międzypaństwowy wymiar tych stosunków. Nie mniej bowiem istotny jest ich aspekt międzyludzki, nierzadko wręcz międzysąsiedzki. Mało kto próbuje wszak rzeczowo dociekać, jakie były źródła oraz skala ruso- i polonofobii oraz stereotypów pokutujących z zadziwiającym uporem do chwili obecnej po obu stronach polsko-rosyjskiej granicy ${ }^{90}$. Historycy chętniej opisują ich przejawy, nierzadko tragiczne w skutkach.

Do napięć między obu nacjami dochodziło często, zwłaszcza w okresie gwałtownych zwrotów dziejowych. Takim momentem był również wybuch I wojny światowej, aczkolwiek uwaga nasza dotyczy bynajmniej nie wszystkich Rosjan i nie wszystkich Polaków. Z pewnością odnosi się jednak do wkraczających do Królestwa Polskiego strzelców z jednej strony i zamieszkujących ziemie polskie Rosjan z drugiej. Wielu ochotników w strzeleckich

${ }^{90}$ Czytelnika odesłać należy do fundamentalnych prac takich autorów jak Andrzej Walicki czy Andrzej de Lazari, zob. przykładowo: A. Walicki, Russia, Poland, and universal regeneration: studies on Russian and Polish thought of the romantic epoch, Notre Dame 1991; idem, Aleksander Hercen. Kwestia polska i geneza pewnych stereotypów, Warszawa 1991; idem, Philosophy and romantic nationalism: the case of Poland, Notre Dame 1994; idem, Rosja, katolicyzm i sprawa polska, Warszawa 2003; idem, A history of Russian thought: from the enlightenment to marxism, transl. from the polish by H. Andrews-Rusiecka, Stanford 2004; Wzajemne uprzedzenia między Polakami i Rosjanami. Materiaty konferencyjne, Łódź, 2-5 grudnia 2001, red. A. de Lazari, Łódź 2001; Dusza polska i rosyjska (od Adama Mickiewicza i Aleksandra Puszkina do Czestawa Mitosza i Aleksandra Sotżenicyna). Materiaty do „katalogu” wzajemnych uprzedzeń Polaków i Rosjan, red. A. de Lazari, Warszawa 2004; Katalog wzajemnych uprzedzeń Polaków i Rosjan, red. A. de Lazari, Warszawa 2006; Polacy i Rosjanie - przezwyciężanie uprzedzeń, red. A. de Lazari i T. Rongińska, Łódź 2006. 
mundurach miało jak najgorsze własne doświadczenia z władzami rosyjskimi z okresu walki o szkołę polską podczas rewolucji lat 1905-1907. Nie bez znaczenia były wartości wyniesione przez nich z domów rodzinnych, gdzie nastawienie antyrosyjskie nierzadko było dominujące, bo bazowało na pamięci krzywd czynionych Rzeczypospolitej i Polakom, co najmniej od czasów Katarzyny II. Nadzwyczaj często oba poruszone aspekty się uzupełniały, w czym pomagała patriotyczna literatura. Uchodźcy z imperium rosyjskiego stanowili tymczasem niemały odsetek strzelców, później legionistów, i nie będzie przesadą stwierdzenie, że to właśnie oni byli bardziej radykalni w swoich antyrosyjskich postawach ${ }^{91}$. Z kolei Rosjanie, zwłaszcza wywodzący się ze sfer politycznych, administracyjnych i urzędniczych, uważali Polaków za niebezpieczny, krnąbrny, zanarchizowany i skłonny do gwałtownych antypaństwowych czynów rozsadnik należącego do nich imperium. Widzieli w nich zarzewie spisków, działań konspiracyjnych, tendencji odśrodkowych, zawsze groźnej irredenty. Tępili niesiony przez Polaków bakcyl wolności, postrzegany w kategoriach realnego zagrożenia stabilności państwa carów i możliwe ognisko buntów ich poddanych, niekoniecznie tylko polskiej narodowości.

Analizując materiały źródłowe dotyczące obecności słynnej rodziny Nabokowów w Kacicach, należy stwierdzić, że jest to wątek zapomniany, a nawet nieznany. Uwaga ta odnosi się zarówno do mieszkańców wioski, jak i historyków. Ci pierwsi pamiętają co najwyżej, że dwór kacicki należał ongiś do „jakichś Rosjan”. O budynku krąży zresztą legenda, według której jest on nawiedzany przez ducha kobiety uznanej za czarownicę i spalonej na stosie w pobliżu zabudowań dworskich. Często jakoby usłyszeć można rozmowy prowadzone przez nieboszczkę. Solidna wiedza historyczna nie po raz pierwszy przegrywa więc z fantastyczną opowieścią przekazywaną zapewne z pokolenia na pokolenie. Ci drudzy z kolei dzieje rosyjskich ziemian zamieszkujących ziemie polskie podczas zaborów traktują przeważnie jako historię obcą, oddzieloną wyraźnie od naszej własnej. Bariery te niełatwo przełamać nawet i dziś. Najczęściej prace poświęcone okresowi przełomu XIX i XX wieku, a odnoszące się do Królestwa Polskiego dotyczą charak-

${ }^{91}$ Przykłady takich postaw zob. M. Wołos, Stowarzyszenie Młodzieży PostępowoNiepodlegtościowej „Promień” w Krakowie w latach 1910-1914 (w druku). 
terystyki postaw społeczeństwa polskiego wobec popowstaniowej rzeczywistości, w tym władzy zaborczej ${ }^{92}$. Więcej miejsca w rodzimej historiografii poświęcono mniejszości żydowskiej zamieszkującej ziemię miechowską ${ }^{93}$. O roli i wkładzie Rosjan w rozwój Królestwa Polskiego w XIX i na początku XX wieku napisano niewiele ${ }^{94}$. O codziennym ich współżyciu z polskimi sąsiadami jeszcze mniej. To wciąż zaniedbany obszar badawczy.

Położone nieopodal Słomnik Kacice mają swoją długą i interesującą historię $e^{95}$. Odwiedzając dziś tę niewielką miejscowość, trudno oprzeć się wrażeniu, iż przenosimy się z powrotem w przeszłość. Dwór znajduje się na samym początku wsi od strony Słomnik, na granicy Januszowic (dziś należy do tej ostatniej wsi), w otoczeniu mnóstwa zieleni i dzikiego parku. Gdyby nie brukowana droga, niewiele świadczyłoby o upływie lat. Znakiem czasu, jaki przykuwa wzrok zwiedzającego, jest zamknięta brama. Co interesujące, dwór nie jest jedynym reliktem przeszłości, jakim szczycą się Kacice. Można odnaleźć tutaj zabudowania z początku XX wieku, do których zaliczamy murowaną szkołę, młyn i kilka domów, a także inne budynki o historii sięgającej roku 1880. Sam zespół dworski był wielokrotnie rozbudowywany. Choć swoją historię zaczyna w XVI stuleciu, odnajdujemy również relikty kaplicy będącej jego częścią pochodzące z XIII wieku. Dwór kacicki przebudowano także w XIX wieku. Obecnie jego remont trwa od roku 1991, czyli od momentu przejęcia go przez prywatnych właścicieli. Do zespołu dworskiego zaliczamy również spichlerz z końca XIX wieku oraz pozostało-

92 Przykładowo: L. Michalska-Bracha, Powstanie styczniowe w pamięci zbiorowej spoteczeństwa polskiego w okresie zaborów, Kielce 2003, s. 71.

93 Przykładowo: Z. Pęckowski, Miechów. Studia z dziejów miasta i ziemi miechowskiej do roku 1914, Kraków 1967; A. Penkalla, Żydowskie ślady w województwie kieleckim i radomskim, Radom 1992.

${ }^{4} \mathrm{Na}$ tym tle wyróżnia się ogłoszona niedawno książka Anny Bażenowej z Instytutu Europy Środkowo-Wschodniej w Lublinie, zob. A. Bażenowa, Historycy Cesarskiego Uniwersytetu Warszawskiego 1869-1915: nauka i polityka, Lublin 2016.

${ }_{95}$ Stownik geograficzny Królestwa Polskiego i innych krajów stowiańskich, t. 3, red. F. Sulimierski, B. Chlebowski, W. Walewski, Warszawa 1882, s. 649-650; E. KubicaKabacińska, I. Mianowska, Rezultaty badań przeprowadzonych $w$ domniemanej kaplicy pocysterskiej w Kacicach, „Czasopismo Techniczne. Architektura” (2011), z. 23, s. 461-469 (tu więcej literatury). 
ści parku z XVII wieku. Przez miejscowość biegnie mało uczęszczana droga otoczona polami uprawnymi.

Majorat kacicki od zawsze związany z gminą Słomniki nie doczekał się opracowań. Uwagę badaczy, ze wskazaniem na historyków sztuki, archeologów i architektów, w pierwszym rzędzie przyciągał budynek dworu należącego ongiś do cystersów, zwłaszcza zaś relikty wspomnianej średniowiecznej kaplicy. W wydanej niedawno monografii znaleźć możemy ledwie lakoniczną wzmiankę: „Kacice, czyli dawny klucz kacicki znalazły się w rękach Dymitra Nabokova dziadka słynnego pisarza Vladimira Nabokova autora "Lolity». Zostały mu przekazane przez zaborcę jako donacja, czyli darowizna za zasługi" "96. Historia rodziny Nabokowów w Kacicach czeka jeszcze na swojego badacza. Spróbujmy zatem niektóre wątki wyjaśnić.

Przez kilka dziesięcioleci majorat kacicki, składający się z kilku majątków o różnej wielkości położonych na zachód i północ od Słomnik, należał do znanej i wielce zasłużonej dla Rosji, starej ziemiańskiej rodziny Nabokowów, z której wywodził się słynny pisarz Władimir Władimirowicz (1899-1977) i nie mniej znany kompozytor Nikołaj (Nicolas) Dymitrowicz (1903-1978). Obaj zrobili światowe kariery na zachodzie Europy i w Stanach Zjednoczonych jako wygnańcy z ojczyzny po przejęciu władzy przez bolszewików. Ich dziadek Dymitr Nikołajewicz Nabokow (1827-1904) otrzymał Kacice za zasługi dla caratu i państwa rosyjskiego po upadku powstania styczniowego. Według urzędowych danych stało się to w 1867 roku. Była to nagroda, ale i zarazem element carskiej polityki wzmacniania rosyjskości nie tylko w większych ośrodkach Królestwa Polskiego, lecz także w zdominowanej przez Polaków wsi, w tym konkretnym przypadku położonej w terenie przygranicznym w pobliżu Krakowa. Składający się z kilku majątków majorat przynosił w latach siedemdziesiątych XIX wieku dochód roczny w wysokości 3 tys. rubli ${ }^{97}$. Było to niemało, jeśli porównamy, że

96 K. Skrężyna, Monografia Stomnik, cz. 2, Słomniki 2015, s. 38.

97 Список гражданским чинам первых трех классов. Исправлен по 15-е января 1870 года, Санкт-Петербург [1870], s. 175-176; Список гражданским чинам первых четьрех классов. Исправлен по 10-е января 1873 года, ч. 1: Чины первых трех классов, Санкт-Петербург 1873, s. 149-150; Список гражданским чинам первых трех классов. Исправлен по 1-е июня 1878 года, Санкт-Петербург 1878, s. 69; Список гражданским чинам первых трех классов. Исправлен по 1-е октября 1893 года, Санкт-Петербург 1893, s. 9-10. 
średnia płaca miesięczna w imperium rosyjskim w 1870 roku wynosiła 25,53 rubli, a za roczną prenumeratę poczytnego dziennika „Московские ведомости” w 1871 roku trzeba było zapłacić 12 rubli $^{98}$. Otrzymanie Kacic przez Dymitra Nikołajewicza nie było bynajmniej sprawą przypadku. Piął się on bowiem coraz wyżej po szczeblach urzędniczej i politycznej kariery, ciesząc się sympatią oraz zaufaniem kolejnych imperatorów, którzy mieli zwyczaj materialnie nagradzać wiernych poddanych. Prawnik z wykształcenia, pracował od 1850 roku w Ministerstwie Sprawiedliwości. Jeszcze przed powstaniem styczniowym los związał go z Królestwem Polskim. W czerwcu 1862 roku został jako hofmeister współpracownikiem ówczesnego namiestnika Królestwa wielkiego księcia Konstantego Nikołajewicza Romanowa. W 1864 roku został senatorem, a w latach 1867-1876 był naczelnikiem Kancelarii Osobistej Jego Cesarskiej Mości, w tym czasie cara reformatora Aleksandra II, mając w swoich kompetencjach sprawy Królestwa Polskiego. Do jego głównych zadań należało wprowadzenie reform sądowych na ziemiach polskich. Warto dodać, że otrzymał także Medal za Uśmierzenie Buntu Polskiego 1863-1864, co traktować należy jako wyraz jednoznacznie negatywnego stosunku właściciela Kacic do polskich zmagań o niepodległość. Był to ledwie początek kariery Dymitra Nabokowa, który w 1876 roku został członkiem Rady Państwa, a w latach 1878-1885 był ministrem sprawiedliwości, stając się tym samym jednym z najbliższych współpracowników Aleksandra II i Aleksandra III. Do jego dymisji przyczynić się miały publikacje najbardziej wpływowego dziennikarza, znanego zresztą z wielkiej niechęci do Polaków, Michaiła Katkowa, którego cięte pióro nie pozostawało bez wpływu nawet na losy ministrów. Nietuzinkową postacią była również żona Dymitra Nikołajewicza - Maria Ferdinandowna Korff (1842-1926), właścicielka majątku Batowo, który w 1913 roku zdecydowała się sprzedać, by osiąść niedaleko Petersburga - w Gatczynie. W przeciwieństwie do męża, Marii dane było dożyć upadku monarchii Romanowów i końca świata rosyjskiej arystokracji oraz ziemiaństwa, którego kres przyniosły wydarzenia rewolucyjne 1917 roku wraz z ich następstwami. Na szczęście udało jej się zachować życie. Uciekła z Rosji ukryta w wagonie towarowym i osiedliła się wraz z rodziną najpierw w Berlinie, póź-

98 „Московские ведомости” 3 VIII 1871, nr 167, s. 1. 
niej zaś Dreźnie, dokąd przybyła w 1922 roku. Ostatecznie osiadła jednak w Rumunii, gdzie zmarła. W swojej biografii „Speak, Memory” Władimir Nabokow wspominał o wydarzeniu z 1859 roku, kiedy to matka Marii, a zarazem prababcia autora, zabrała wtedy siedemnastoletnią córkę wraz z jej młodszą siostrą Olgą na wystawny bal w Paryżu. Zatem dziewczyna od dzieciństwa obracała się w wyższych sferach, co w niedalekim czasie zaowocowało małżeństwem z Dymitrem Nabokowem ${ }^{99}$.

Po śmierci Dymitra Nikołajewicza Kacice przejął jego syn i zarazem ojciec kompozytora Dymitr Dymitrowicz Nabokow (1867-1949?). Jego pierwszą żoną była Lidia Eduardowna Falz-Fein (1870-1937), wywodząca się z arystokratycznej rodziny o niemieckich korzeniach. Małżonkowie rozstali się około 1909 roku. Drugą żoną Dymitra została Maria (Marie) Redlich. Dymitr Dymitrowicz był ziemianinem, prawnikiem i urzędnikiem państwowym w randze radcy stanu. W 1888 roku ukończył Imperatorską Szkołę Prawa w Petersburgu. Był sędzią pokoju II okręgu kieleckiej guberni. Po przejęciu władzy przez bolszewików znalazł się na emigracji w Niemczech, gdzie dożył późnej starości ${ }^{100}$. Nie zrobił jednakże tak znamienitej kariery jak rodzic czy choćby trzej jego bracia, spośród których wyróżnić należy Władimira Dymitrowicza Nabokowa (1869-1922), ojca wspomnianego wyżej pisarza. W odróżnieniu od większości członków rodziny Władimir Dymitrowicz był przeciwnikiem caratu, przekonanym demokratą i liberałem oraz jednym z liderów Partii Konstytucyjno-Demokratycznej, którą reprezentował w I Dumie Państwowej. Zginął zastrzelony

99 Альманах современных русских государственных деятелей, Санкт-Петербург 1897 , s. 23-24; Набоков Амитрий Николаевич, [w:] Энииклопедический словарь Брокгауза и Ефрона, т. ХХ, Москва 1897, s. 396-397; Н. А. Пашенный, Императорское Училище Правоведения и Правоведы в годы мира, войнь и смутыл, Малрих 1967, s. 102, 277; Н. И. Канищева, Набоков Владимир Амитриевич, [w:] Государстенная Аума Российской империи 1906-1917. Энииклопедия, отв. реА. В. В. Шелохаев, Москва 2008, s. 390 (tu biogram jego syna Władimira Dymitrowicza Nabokowa, o którym niżej, wraz z podstawowymi informacjami o ojcu). Sporo na temat antenatów Dymitra Nikołajewicza Nabokowa i o nim samym zob. B. Boyd, Vladimir Nabokov. The Russian Years, New Jersey 1990, s. 15-35; V. Nobokov, Speak, Memory: an autobiography revisited, New York 1989, s. 56-57 (tu informacje o Marii Korff); А. Зверев, Набоков, Москва 2016, s. 20-22 (tu informacje o rodzinnych koneksjach Marii Ferdinandownej i Dymitra Nikołajewicza Nabokowów).

${ }^{100}$ Н. А. Пашенный, op. cit., s. 173. 
na emigracji w Berlinie, wykazując się niezwykłą odwagą, bo stając bez wahania w obronie przywódcy swojej politycznej orientacji Pawła Milukowa, na którego próbowali dokonać zamachu rosyjscy monarchiści, także polityczni emigranci ${ }^{101}$. Inny z braci - Siergiej Dymitrowicz (1866-1940) śladami ojca piął się po szczeblach kariery w Ministerstwie Sprawiedliwości. Warto dodać, że był on między innymi prokuratorem w Nowoczerkasku i Warszawie. Zwieńczył służbę na stanowisku gubernatora Kurlandii, ostatniego zresztą z ramienia carskich władz. Zmarł na emigracji w Bukareszcie $^{102}$. Najmłodszy z braci - Konstantin Dymitrowicz (1872-1927) był dyplomatą, choć karierę zaczynał również w Ministerstwie Sprawiedliwości. W 1905 roku uczestniczył w negocjacjach w Portsmouth kończących wojnę rosyjsko-japońską. Potem był pierwszym sekretarzem w rosyjskich placówkach dyplomatycznych w Berlinie i Waszyngtonie, a w latach 1912-1915 konsulem generalnym w Kalkucie. Uniknął tragedii, oddając zakupiony już wcześniej bilet na feralny rejs „Titanica”. W 1916 roku został radcą ambasady w Wielkiej Brytanii, którą to placówką po rewolucji lutowej przez jakiś czas kierował w charakterze posła nadzwyczajnego. Obiecująco rozwijającą się karierę dyplomatyczną Konstantina przerwało dojście do władzy bolszewików. Podobnie jak pozostali bracia, znalazł się na emigracji, najpierw w Norwegii, później zaś w Londynie, gdzie zmar1 ${ }^{103}$.

Dymitr Dymitrowicz i Lidia Eduardowna Nabokowowie spędzali większość czasu w głębi ówczesnej Rosji, ze wskazaniem na Petersburg

${ }^{101}$ Н. И. Канищева, ор. cit., s. 390-391; Г.Чернявский, А. Аубова, Милюков, Москва 2015, s. 402-407; М. Соколов, Соблазн активизма. Русскал республиканско-демократическая эмиграчия 20-30-х гг. ХХ века и ОГПУ СССР, Москва 2011, s. 51.

102 Список гражданским чинам IV класса на 1907 год, Санкт-Петербург 1907, s. 2659; Список гражданским чинам первых четьлё̈х классов, ПетрограА 1914, s. 868;

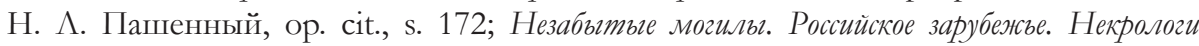
1917-1999, т. 5, сост. В. Н. Чуваков, Москва 2004, s. 16.

103 Konstantin pozostawił po sobie wspomnienia, w których opisał własne losy na tle rosyjskiej polityki zagranicznej, począwszy od pracy w Kalkucie: К. А. Набоков, Испьтания дипломата, Стокгольм 1921, s. 9 і n.; zob. także: А. С. Клейн, Аругая сторона светила: Необъчная любовь въгдающихся людей. Российское созвездие, Санкт-Петербург 2002, s. 367 i n. (rozdział pt. Семейство Набоковых и гомосексуальность); Чему свидетели мьг бъли... Переписка бывиих чарских дипломатов 1934-1940 г2. Сборник документов, книга вторая: 1938-1940, Москва 1998, s. 365, 394-396. 
i należący do małżonki piękny Lubcz nad Niemnem. Ani Lidia, ani zajęty muzyczną karierą jej syn Nikołaj nie poświęcali nadmiernej uwagi gospodarowaniu nadniemeńskim majątkiem, co skutkowało coraz gorszym jego prosperowaniem. Tymczasem po rozwodzie Dymitr Dymitrowicz wraz z drugą żoną chętniej odwiedzał Kacice. Z obu małżeństw Dymitr miał aż sześcioro dzieci. Jeden z jego synów, Władimir urodził się w Kacicach 26 lipca 1912 roku. Rodzina Nabokowów lubiła spędzać letnie miesiące w swoim dworze w pobliżu Słomnik. Nic zatem dziwnego, że wybuch wielkiej wojny zastał część familii właśnie tam ${ }^{104}$. Dysponujemy precyzyjnymi informacjami na temat stanu majątku w Kacicach w 1916 roku. Z publikacji wydanej przez austriackie władze okupacyjne wynika, że majorat kacicki jako dobra donacyjne w dalszym ciągu pozostawał własnością Dymitra Dymitrowicza Nabokowa. Dzielił się on na następujące majątki: Kacice (844 morgi, zarządca Jan Kowalski), Bazary (63 morgi, zarządca Jan Zdeb), Granów (500 morgów, zarządca Stanisław Głosiński) i Gosnówka (330 morgów, zarządca Majer Goldkorn). Zarządcami byli zatem głównie Polacy, aczkolwiek nie mamy informacji, czy zostali oni powołani do pełnienia swych obowiązków jeszcze przez Nabokowa, czy też już przez Austriaków. Część majoratu z rozrzuconymi wokół Słomnik majątkami Nasiechowice, Dziewięcioły, Januszowice, Lipna Wola i Łososkowice była własnością małoletniej Wiery Pisariew, będącej pod opieką matki. W samych Kacicach znajdowały się wówczas 62 domy zamieszkiwane przez 753 mieszkańców. Wszyscy byli rzymskimi katolikami ${ }^{105}$. Jak widać, Austriacy nie wywłaszczyli rosyjskich właścicieli majątków, uznając ich prawo własności do majoratu. Na marginesie warto dodać, że w ziemi miechowskiej było jeszcze kilka innych dóbr donacyjnych należących do Rosjan.

Tutaj dopiero zaczynamy właściwą opowieść. Strzelcy ze słynnej Pierwszej Kompanii Kadrowej pierwszą noc po przekroczeniu w Michałowicach granicy austriacko-rosyjskiej i obaleniu słupów dzielących wbrew woli Polaków ich ziemie spędzili w Słomnikach. Rano 7 sierpnia 1914 roku komendant II plutonu Henryk Paszkowski („Krok”) otrzymał rozkaz wy-

104 V. Giroud, Nicolas Nabokov. A Life in Freedom and Music, Oxford 2015, s. 2-3.

105 Obwód Miechowski w okupowanej Polsce 1916 r., na polecenie c. i k. Komendy Obwodowej zestawili nadporucznik W. Dubaj i mjr R. Weber, Miechów [1916], s. 30, 40. 
znaczenia pięcioosobowej załogi, która nie pomaszeruje dalej wraz z Kompanią Kadrową, ale pozostanie w Słomnikach, aby pełnić funkcję łącznika między Krakowem, jako najbliższym zapleczem strzelców, a przesuwającymi się dalej w głąb Królestwa czołowymi pododdziałami. Było to zadanie rzecz jasna czasowe, ale niechętnie przyjmowane przez młodych żołnierzy-powstańców, którym marzyły się wielkie czyny na pierwszej linii frontu, a nie nudna służba na jego zapleczu. Rozkaz był jednak rozkazem. W skład załogi wyznaczono Zygmunta Przepałkowskiego („Młot”, 1893-1940) jako komendanta, Kazimierza Kamieńskiego („Luboń”, 1891-1914) rychło mianowanego zastępcą, Seweryna Maciszewskiego („Wład”, 1892-1973), Bolesława Mierzejewskiego („Strzecha”, ur. 1895) i Henryka Dobrowolskiego („Sęk”, 1895-1914). Wszyscy wymienieni pochodzili z terenów imperium rosyjskiego, co zapewne nie było bez znaczenia podczas rekrutowania w szeregi owej maleńkiej słomnickiej załogi. „Młot” wiosną 1940 roku został zamordowany przez sowietów w Katyniu. „Lubon’”, który zresztą zginął w grudniu 1914 roku podczas bitwy pod Łowczówkiem, przybył do strzeleckich szeregów aż z Petersburga, gdzie zdążył już zapisać interesującą kartę w swej działalności niepodległościowej. Podobną drogę ze stolicy imperium rosyjskiego do Krakowa przebył „Wład”, który dożył sędziwego wieku, a na kilka miesięcy przed wybuchem II wojny światowej został nawet wiceministrem wyznań religijnych i oświecenia publicznego w ostatnim gabinecie międzywojennej Polski, kierowanym przez kolegę z legionowych szeregów gen. Sławoja Felicjana Składkowskiego. Pod Łowczówkiem poległ również niespełna dwudziestoletni „Sęk”. Najmniej informacji posiadamy o „Strzesze", którego władze II Rzeczypospolitej na początku lat trzydziestych nie były w stanie odnaleźć, aby wręczyć mu przyznany Krzyż Niepodległości. Najpewniej przebywał wówczas poza granicami Polski na emigracji ${ }^{106}$. Jak widać z tego krótkiego przeglądu, dalsze losy członków załogi słomnickiej

106 J. M. Majchrowski, Pierwsza Kompania Kadrowa. Portret oddziatu, Kraków 2014, s. 103, 126, 142-143, 145, 160; J. Matejko, Kamieński Kazimierz, pseud. Luboń, [w:] Polski Stownik Biograficzny (dalej: PSB), t. 11, Wrocław-Warszawa-Kraków 1964-1965, s. 538-539; K. Bartnicka, Maciszewski Seweryn Wtadystaw, [w:] PSB, t. 19, WrocławWarszawa-Kraków-Gdańsk 1974, s. 80-82; S. Pomarański, Z historycznych dni lipca i sierpnia 1914 r., Warszawa [1936], s. 33; Kazimierz Luboń-Kamieński, Warszawa 1936; Z. Przepałkowski-(Młot), Jak awansowatem na kadrowca, „Strzelec. Organ Związku 
były w większości przypadków tragiczne. Aż trzech wymienionych wyżej strzelców straciło życie z rąk wschodnich sąsiadów.

Członkowie załogi ulokowali się w budynku urzędu gminnego, który stał się ich kwaterą na czas pełnienia służby w Słomnikach i ich najbliższej okolicy. Przepałkowski pomyślał nawet i o tym, aby mianować łącznika między strzelcami, głównie zaś nim samym, a miejscową społecznością. Został nim staruszek nazywany przez słomniczan po prostu „Polska”, ponieważ w przeciwieństwie do większości mieszkańców miasta nie miał żadnych skrupułów, aby okazywać publicznie swoje patriotyczne uczucia i czynnie wspierać strzelców. Pod strzelecką kuratelą pojawił się też zaczątek polskich władz samorządowych. Naczelnikiem miasta został jego mieszkaniec Bogusław Kowalski ${ }^{107}$. Nie mamy pewności, czy był on tożsamy z obywatelem „Polską”. Niewykluczone, że ten sam Bogusław Kowalski był członkiem komisji aprowizacyjnej obwodu miechowskiego, działającej później za zgodą austriackich władz okupacyjnych ${ }^{108}$.

Tymczasem większość słomniczan patrzyła na odzianych w dziwaczne zapewne dla nich mundury przybyszów z Krakowa wstrzemięźliwie, by nie powiedzieć, że wręcz z obawami, mając na względzie możliwość rychłego powrotu Rosjan i potencjalne represje za wspieranie - jak to wówczas mówiono w języku propagandy rosyjskiej - „polskich sokołów”. Mieszkająca w nieodległych Goszycach Zofia Zawiszanka, aktywna działaczka niepodległościowa już wcześniej związana z ruchem strzeleckim, kilkanaście lat po wydarzeniach napisała, że Słomniki przyjęły wkraczających żołnierzy polskich „z rodzajem radosnego niepokoju” ${ }^{109}$. Akcent należałoby wszakże położyć na ostatnie z cytowanych słów, a zbeletryzowany tekst Zawiszanki o stosunku mieszkańców miasta do strzelców potraktować jako pisany post factum „ku pokrzepieniu serc”. Tak pięknie nie było, bo wśród słomniczan dominowały obawa i niepewność jutra. Przepałkowski okazał się

Strzeleckiego”, 5 sierpnia 1934, nr 31, s. 97-98; K. Skrężyna, op. cit., s. 56 (autorka jako komendanta słomnickiej załogi wymienia „Lubonia”).

107 K. Skrężyna, op. cit., s. 56.

108 Obwód Miechowski w okupowanej Polsce, s. 21.

109 Z. Zawiszanka, Poprzez fronty. Pamiętnik wywiadowczyni 1 Putku Piech. Leg. Z 1914 roku. Na podstawie notatek spisanych w lutym - marcu 1915 r., Warszawa 1928, s. $20-22$. 
komendantem wykazującym się inicjatywą i szybko opracował plan działań na najbliższe dni, wczuwając się w rolę gospodarza występującego w imieniu władzy polskiej, jakiej ziemie te od dawna nie zaznały. Nakazał nade wszystko powołać do życia w Słomnikach Komitet Obywatelski. Z kolei swoim podkomendnym zlecił zadania w terenie. Trzyosobowe patrole miały dotrzeć do Goszczy i Goszyc, aby na miejscu zbadać nastroje ludności, wypytać o rosyjską straż graniczną i wreszcie wydać odpowiednie rozporządzenia, jak chociażby to o przekazaniu do Słomnik drzewa, które chłopi zdążyli już zrabować pod nieobecność jakiejkolwiek władzy z okolicznych lasów państwowych. Dla nas interesujący był inny rozkaz „Młota”:

Patrol z 3-ch ludzi dotrze do wsi Kacice, sprawdzi czy rzeczywiście majątek ten został skonfiskowany po 1863 r. i nadany przez rząd rosyjski ojcu obecnego właściciela, Nabokowowi, zbada jego papiery i dokumenty i poleci mu stawić się w Słomnikach do dyspozycji Komendanta załogi $^{110}$.

Mając na względzie wybitnie szczupłe, bo ledwie pięcioosobowe siły, strzelcy przemyśliwali pierwotnie wysłać do Kacic po Nabokowa zaufanych cywilów. Sami zaś, zostawiając komendanta i jednoosobową wartę w Słomnikach, ruszyli ku Goszczy i Goszycom. Wizytę patrolu w Kacicach odłożono na później. Członkowie załogi mieli zresztą co robić w Słomnikach, przez które ku Miechowowi przeciągały inne strzeleckie oddziały oraz wojska austriackie. Szczególne wrażenie robili jednak politycy socjalistyczni i działacze niepodległościowi, w tym Gustaw Daniłowski, Ignacy Daszyński, Emil Haecker, Wacław Sieroszewski, Włodzimierz Tetmajer, Leon Wasilewski, a także pisarz gminny Błażej Czepiec, znany powszechnie dzięki „Weselu” Stanisława Wyspiańskiego jako wójt z Bronowic. Zresztą Czepiec rwał się do czynu tak gwałtownie, że obywatel „Polska” musiał go „własnoręcznie mitygować" 111 .

W Kacicach w majątku Nabokowów jako pierwsi pojawili się strzelcy z konnego oddziałku Władysława Prażmowskiego („Belina”). Działo się to

110 S. Maciszewski (Wład), Zatoga stomnicka, „Strzelec. Organ Związku Strzeleckiego”, 5 sierpnia 1934, nr 31, s. 162.

111 Ibidem. 
rano 7 sierpnia 1914 roku. Beliniacy stanowili awangardę Pierwszej Kompanii Kadrowej. Ich zadanie polegało na patrolowaniu i osłonie nie tylko samej szosy na Miechów, ale także w miarę szerokiego pasa po obu jej stronach. Właśnie dlatego jeden z patroli trafił do nieodległych od traktu Kraków-Kielce Kacic. Jednak czy tylko względy bezpieczeństwa zawiodły podkomendnych „Beliny” do majątku Nabokowów? Można w to powątpiewać. Tworzącej się właśnie wówczas strzeleckiej kawalerii brakowało broni, wyposażenia i koni. Najłatwiejszym sposobem ich zdobycia była rekwizycja zwierząt ze stajni należących do rosyjskiego ziemianina, postrzeganego przecież jako ucieleśnienie wroga. Liczono zapewne na to, że w majoracie znajdzie się jeśli nie wszystko, to wiele cennych przedmiotów oraz dobrze utrzymany inwentarz potrzebny do dalszej wojaczki. Skoro strzelcy nie wahali się przeprowadzać rekwizycji u Polaków, to jakaż bariera mogła ich zatrzymać przed konfiskatą majątku należącego do Rosjan? W opracowaniu dotyczącym pierwszych dni kawaleryjskiej epopei beliniaków mjr Janusz Żuławski zapisał wymowne zdanie: „Ponadto jeden patrol idzie do Kacic, majątku rosjanina [tak w tekście - M.W., E.K.] Nabokowa, skąd zabiera znalezioną broń i rekwiruje konie dla oddziału"112. Ten sam autor napisał jeszcze, że w Kacicach kawalerzyści spotkali komendanta słomnickiej załogi Zygmunta Przepałkowskiego, który miał wstąpić do oddziału, zamieniając

112 Archiwum Instytutu Józefa Piłsudskiego w Ameryce, Nowy Jork (dalej: AIJP/NJ), Zespół 028: Legiony, POW, Naczelny Komitet Narodowy 1914-1918 (dalej: Legiony), sygn. 3, Mjr. Żuławski, Marsz na Kielce i pierwsze zajęcie Kielc 6-13.VIII.1914 r. (mps, s. 3), k. 86. Co ciekawe, o tej wizycie beliniackiego patrolu w Kacicach nie wspomina nader dokładny dziejopis 1 Pułku Ułanów Legionów Polskich i zarazem jego żołnierz Józef Smoleński („Kolec”), zob. J. Smoleński-Kolec, I Putk Utanów Leg. Pol. Beliny im. Józefa Pitsudskiego /zarys historyczny/, cz. 1: Rok 1914, „Beliniak” (1958), nr 8-9, s. 9. Tymczasem Leszek Moczulski napisał w swoim obszernym opracowaniu o zarekwirowaniu przez beliniaków „paru dobrych koni” w „majoracie grafa Nabokowa”, ale błędnie wskazał, że stało się to „dopiero za Jędrzejowem”. Ponadto jako jego właściciela wymienił bezimiennego „gen. Nabokowa”, jakoby stryjecznego dziada pisarza Władimira, ewidentnie myląc go z ministrem Dymitrem Nikołajewiczem Nabokowem. Na koniach zarekwirowanych Rosjanom sztab strzelecki miał wjechać do Kielc, co nie wydaje się niemożliwe, zob. L. Moczulski, Przerwane powstanie polskie 1914, Warszawa 2010, s. 263, 329. 
tym samym służbę w piechocie na końskie siodło ${ }^{113}$. Informacja ta nie wydaje się jednakże zbyt precyzyjna, ponieważ „Młot” musiałby złamać rozkaz wydany mu przez Paszkowskiego. Prawdą jest, że do kawalerii wstąpił kilka dni później i zapewne stąd pomyłka Żuławskiego. Niewykluczone wszak, iż faktycznie 7 sierpnia rano pojawił się wraz z konnym patrolem w Kacicach, aby wykonać cytowane wyżej zadanie, które sam postawił przed załogą słomnicką. Byłaby to zarazem odpowiedź na pytanie, skąd jakiś czas później w Słomnikach przed obliczem tegoż Przepałkowskiego wziął się Dymitr Dymitrowicz Nabokow. Sprawa rekwizycji strzeleckich przeprowadzanych w Kacicach miała swój dalszy ciąg.

W niedzielę 9 sierpnia zjechali do Słomnik chłopi z okolicznych wsi, co zawsze sprzyjało wymianie poglądów i zdobywaniu informacji. Po sumie odbyła się procesja w Rynku, która została zwieńczona przed kwaterą strzeleckiej załogi. Komendant Przepałkowski nakazał publicznie wystąpić swojemu zastępcy „Luboniowi” Kamieńskiemu, który zresztą uchodził wśród znających go kolegów za świetnego mówcę. Ten zaś zanotował w swoim dzienniku: „Zdaje mi się, że zrobiłem wrażenie, chłopy beczeli, jak bobry. Pierwszy raz mówiłem do chłopów, biłem więc przeważnie na uczucie: po stu latach przychodzimy, wojsko polskie, za wolność i lud, sam ledwo się nie rozpłakałem" ${ }^{\prime 14}$.

Wszelako wszystko tak pięknie, błogo i romantycznie nie wyglądało. Ten sam „Luboń” zanotował, że jeszcze przed sumą strzelcy zdążyli dokonać rekwizycji koni. Niestety, nie sprecyzował, czy zwierzęta zabrano ze Słomnik, czy też z okolicznych wiosek, a być może także po raz wtóry z Kacic. Nie podobało się to okolicznym mieszkańcom, którzy realnie rzecz ujmując, nie mogli liczyć na zwrot skonfiskowanej własności. Strzelcy z kolei nie mogli inaczej postępować, bo byli wojskiem ochotniczym i całkowicie w tym czasie pozbawionym dostaw. O żywność, wikt i opierunek, nie mówiąc już o podwodach, musieli dbać własnym sumptem, niekiedy zresztą

113 AIJP/NJ, Legiony, sygn. 3., Mjr. Żuławski, Marsz na Kielce i pierwsze zajęcie Kielc 6-13.VIII.1914 r. (mps, s. 3), k. 86.

${ }^{114}$ K. Luboń-Kamiński [winno być: Kamieński], Dyaryusz Lubonia, [w:] Legiony na polu walki. Dziatania Pierwszego Putku Legionów na lewym brzegu Wisty w sierpniu i wrześniu 1914 roku. Relacye uczestników, zebrał i wstępem zaopatrzył W. Tokarz, Piotrków 1916 , s. 83. 
czyniąc to może nawet nadmiernie ochoczo i stanowczo, co dość jednoznacznie wynika z meldunków wojskowych władz austriackich ${ }^{115}$.

Powróćmy jednakże do biegu interesujących nas wydarzeń. Jeszcze w niedzielę wieczorem przyszedł rozkaz, aby następnego dnia załoga słomnicka odmaszerowała do Miechowa, goniąc macierzystą Pierwszą Kompanię Kadrową. Wciąż nie wykonane wszak pozostało zadanie w Kacicach. Teraz nie można było go już odkładać. Nie do końca wiadomo, kto sprowadził Dymitra Dymitrowicza Nabokowa do Słomnik przed oblicze Przepałkowskiego. Być może on sam jeszcze rano 7 sierpnia, co sugerowaliśmy wyżej. Być może uczynili to owi cywile, o wysłaniu których myślano już wcześniej. Być może Rosjanin stawił się sam posłuszny wezwaniu, zdając sobie sprawę, że spotkanie z nowymi władzami wojskowymi i tak go nie ominie. Zagadki tej pewnie już nigdy nie uda się rozwikłać i bynajmniej nie jest to dla naszych rozważań kluczowe. „Młot” zdecydował się na wydanie orzeczenia lub może lepiej wyroku na Rosjanina oraz majorat w Kacicach dopiero po przestudiowaniu dostarczonych mu dokumentów. Archiwum tymczasem okazało się nadzwyczaj bogate. Za lekturę wzięli się Kamieński z Maciszewskim. Wśród przechwyconej korespondencji znaleźli listy imperatora Aleksandra III (choć w tym przypadku ostatni z wymienionych strzelców w spisanej po latach relacji nie miał pewności, czy faktycznie chodziło o tego władcę, czy też o jego ojca Aleksandra II), teoretyka rosyjskiego konserwatyzmu Konstantina Pobiedonoscewa i innych znaczących postaci życia publicznego imperium Romanowów do Dymitra Nikołajewicza Nabokowa. „Wład”, skądinąd ojciec znanego w Polsce Ludowej historyka i działacza partyjnego Jaremy Maciszewskiego, zanotował we wspomnieniach:

Materjału tego było tak dużo, że do wieczora nie zdążyliśmy się z nim uporać. Studjom położył kres, nadeszły z Miechowa, rozkaz o dołączeniu jutro do kompanji.

115 Galicyjska dziatalność wojskowa Pitsudskiego 1906-1914. Dokumenty, zebrali i oprac. S. Arski i J. Chudek, Warszawa 1967, s. 624 (1914 sierpień 9, g. 15, Folwark Laskowa - Meldunek oficera oddziału zwiadowczego nr 3 Grupy Operacyjnej Kummera dla dowództwa 7 dywizji kawalerii w Miechowie o zachowaniu się oddziałów strzeleckich wobec ludności cywilnej w Królestwie). 
Pobyt w Słomnikach kończył się. Trzeba było coś zrobić z Nabokowym. Rozpoczęła się ogólna narada. Młot był za zastosowaniem jaknajostrzejszych środków represyjnych. Chciał go aresztować i wieźć do Miechowa, - wytłomaczyliśmy mu dość łatwo, że trudno ciągnąć za sobą człowieka tej tuszy co Nabokow, i ostatecznie niewiadomo na coby to się komu przydało. Dokumenty, listy - owszem te można przechować w bezpiecznym miejscu, a po wojnie oddać według przeznaczenia. Młot, acz niechętnie, musiał się zgodzić na takie rozstrzygnięcie sprawy, ale $\mathrm{z}$ oczu jego widać było, że coś jeszcze kryje w zanadrzu ${ }^{116}$.

Trudno nie oprzeć się wrażeniu o porywczości młodego dowódcy, który nie miał powodu kochać Rosjan, ale też nie miał powodu stosować odpowiedzialności pośredniej. Innymi słowy, karać Dymitra Dymitrowicza Nabokowa za działalność jego ojca, bo przecież z przekazu jednoznacznie wynika, iż odnaleziona korespondencja dotyczyła spraw sprzed wielu lat, a nawet dziesięcioleci. Na marginesie jeszcze jedna uwaga - szkoda, że autor wspomnienia nie napisał o dalszych losach przejętego przez strzelców archiwum Nabokowów z Kacic, które zawierało zapewne cenne dla badaczy przeszłości źródła.

Rankiem 10 sierpnia załoga słomnicka na zarekwirowanej furmance ruszyła w stronę Miechowa szosą, którą trzy dni wcześniej przeszła Pierwsza Kompania Kadrowa. Komendant Przepałkowski postawił jednak na swoim. Zrobił to w tak stanowczy sposób, że jego podkomendni zaczęli się obawiać o dalsze losy Nabokowa i jego rodziny. Przez głowę przemknęła im nawet myśl o rozstrzelaniu Rosjan bez sądu. „Młot” nakazał zjechać z szosy w kierunku Kacic, a po przybyciu na miejsce osadzić bagnety na broni. Wzbudziło to niepokój Dobrowolskiego, który próbował protestować. Strzelcy byli wszak wojskiem obywatelskim i tego typu - skądinąd racjonalne, ale przecież godzące $\mathrm{w}$ suche rozumienie militarnej dyscypliny - zachowania nie były im obce. Dwór w Kacicach młodzi żołnierze obeszli gęsiego wokół, jakby badając nieznany teren, po czym weszli do przedpokoju, skutecznie strasząc swoim wyglądem i postawą służącą, zresztą Polkę. Wewnątrz zastali nie tylko Dymitra i Marię Nabokowów, ale jeszcze jedną damę oraz - najpewniej - dwójkę dzieci. Gospodarze, niepewni

116 S. Maciszewski (Wład), op. cit., s. 163-164. 
swej przyszłości, byli przerażeni. Wówczas Przepałkowski, nakazując swoim podwładnym przyjąć postawę zasadniczą, zakomenderował, zwracając się do Nabokowa: „W imieniu rządu Narodowego konfiskuję na rzecz Państwa majątek Kacice, a Pana wyznaczam na administratora. Rachunki i dochody ma Pan składać co kwartał w głównej Komendzie Wojsk Polskich. Proszę otworzyć kasę" ${ }^{117}$. Pieniędzy znaleziono niewiele, nieco ponad 70 rubli, które „Młot” wspaniałomyślnie przekazał na kapitał obrotowy skonfiskowanego majątku, inaczej mówiąc oddał Nabokowowi. Napięcie opadło. Maria Nabokowa najczystszą polszczyzną zaproponowała strzelcom kawę. Ci jednak odmówili, pomni rozkazu szybkiego odjazdu do Miechowa. Kurtuazji stało się zresztą zadość. Żołnierze nie tylko ucałowali na pożegnanie rączki pani domu, ale i przeprosili pana za uczyniony kłopot. Jak widać, konwenanse obowiązywały nawet w wojennych warunkach. Strzelcy opuścili Kacice i odjechali ku szosie Słomniki-Miechów. „Młot” postąpił zresztą jak najbardziej racjonalnie, choć pozornie mogłoby się wydawać, że odegrana scena bardziej pasowała do przedstawienia teatralnego i miała wymiar ze wszech miar kuriozalny ${ }^{118}$. Cóż innego mógł uczynić? Nie miał możliwości w istniejących warunkach przekazać skonfiskowanego majątku komukolwiek zaufanemu. Przyszłość była zbyt niepewna. Nie mógł też ot tak zapomnieć o rosyjskich ziemianach, którzy nawet w obliczu zbliżającego się nieprzyjaciela zdecydowali się pozostać w majątku będącym w posiadaniu ich rodziny od niemal półwiecza. Faktycznie jednak owa strzelecka rekwizycja majoratu nie miała, bo i mieć nie mogła żadnej mocy sprawczej. Bardziej przypominała symboliczny gest.

Dalsze losy należącego do Nabokowów majoratu w Kacicach nie były jednakże szczęśliwe. Strzelcy nie zapomnieli o mieszkających tam rosyjskich właścicielach. Już dzień po opisanych wydarzeniach przebywający w najbliższym otoczeniu Józefa Piłsudskiego Tadeusz Kasprzycki odnotował w swoim dzienniku, że planowana jest kolejna rekwizycja koni z majątku

117 Ibidem, s. 164.

118 M. Wołos, Przerwana droga do Niepodlegtej. Kazimierz Piatek „Herwin” (18861915), Warszawa 2016, s. 105. 
Nabokowów ${ }^{119}$. Nie ma informacji, czy doszła ona do skutku. Nie ulega natomiast wątpliwości, że łupienie należącego do Rosjan majoratu było w opinii strzelców jak najbardziej uzasadnione, bo traktowane w kategorii naprawiania historycznych krzywd czynionych Polakom przez zaborców, a zarazem odwiecznych wrogów. Problemem odpowiedzialności zbiorowej mało sobie przy tym zaprzątano głowę.

Kacice stanęły na drodze już nie strzelców, ale legionistów spod znaku Piłsudskiego po raz kolejny trzy miesiące później, w listopadzie 1914 roku, podczas słynnego przemarszu do Krakowa przez Ulinę Małą. Wówczas to w ich kierunku wysłano patrol kawaleryjski w sile dwóch plutonów pod dowództwem por. Gustawa Dreszera („Orlicz”), którego zadaniem miało być rozpoznanie pozycji nacierających od wschodu i północy Rosjan na linii Władysław-Kacice. Nocą z 10 na 11 listopada do tej ostatniej miejscowości dotarł należący do podjazdu „Orlicza” VI pluton z ppor. Janem Lewandowskim na czele (kawaleria Piłsudskiego nie była jeszcze wówczas podzielona na szwadrony). Oddajmy głos Józefowi Smoleńskiemu:

Zapadła noc, pluton posuwał się wolno, ubezpieczając się tylko szpicą od czoła. Szpica miała rozkaz zatrzymania się przed pierwszymi zabudowaniami wsi Kacice, gdzie według zeznań ludności miał kwaterować oddział rosyjski. Szpica zatrzymała się przed pierwszą samotnie stojącą chatą; dla zbadania jej Lewandowski wysłał pieszo dwóch kaprali [Stefana] Hankę Kuleszę i [Czesława] Skauta Bankiewicza. Wkrótce wrócili, meldując że słyszeli w chacie rozmowę rosyjską. Otrzymali wsparcie czterech ułanów i rozkaz złapania znajdujących się w chacie Rosjan. Napad się udał, złapano dwóch żołnierzy piechoty ros.[yjskiej], którzy zeznali, że zgubili swą kompanię i zanocowali w samotnie stojącej chałupie. Od mieszkańca chaty dowiedziano się, że dalej we wsi jest pełno Rosjan. Lewandowski uznał swoje zadanie za skończone i zawrócił do Władysława ${ }^{120}$.

Kroniki milczą, czy w tym czasie w Kacicach przebywał jeszcze Dymitr Dymitrowicz Nabokow ze swą familią.

119 T. Kasprzycki, Kartki z dziennika oficera I Brygady ze szkicami, mapami i ilustracjami, Warszawa 1934, s. 32 (zapis z 11 sierpnia 1914 roku).

${ }^{120}$ J. Smoleński-Kolec, op. cit., s. 43-47. 
Dzieje rodziny Nabokowów noszą piętno tragicznej historii rosyjskiej arystokracji i inteligencji po objęciu władzy przez bolszewików ${ }^{121}$. Nie wiemy dokładnie, kiedy Dymitr i jego bliscy opuścili Kacice, uchodząc przed wojenną pożogą w głąb Rosji. Czy stało się to jeszcze jesienią 1914 roku, właśnie wówczas kiedy to okolice Słomnik zostały na krótko zajęte przez wojska rosyjskie? Przewrót bolszewicki i przegrana przez białą Rosję wojna domowa wygnała Dymitra i jego rodzinę na zawsze z ojczyzny. Droga wiodła na zachód Europy, do Niemiec, Francji i na kontynent północnoamerykański, gdzie dzielili losy rzesz rosyjskich emigrantów ${ }^{122}$. Po II wojnie ścieżki bodaj najbardziej znanego z Nabokowów, pisarza Władimira, skrzyżowały się jeszcze raz z życiową drogą jednego z byłych legionistów spod sztandaru Piłsudskiego. Otóż w 1948 roku Wacław Jędrzejewicz, ongiś żołnierz batalionu warszawskiego I Brygady Legionów Polskich, otrzymał katedrę języka i literatury rosyjskiej w Wellesley College w Stanach Zjednoczonych, właśnie po Władimirze Nabokowie ${ }^{123}$. Było to o tyle wyjątkowe, że powierzenie takiego stanowiska Polakowi wywoływało niechętne reakcje rosyjskiego środowiska emigracyjnego ${ }^{124}$. Był w tym przypadku i inny jeszcze paradoks. Zarówno rodziny Nabokowów, jak i Jędrzejewiczów były w przeszłości związane z Wyżyną Miechowską. Trzy pokolenia Nabokowów przede wszystkim przez Kacice, Jędrzejewiczowie zaś przez postać Józefa Buchnera, matczynego dziadka premiera Janusza Jędrzejewicza i ministra Wacława Jędrzejewicza, który był w czasie powstania styczniowego leka-

${ }^{121} \mathrm{Na}$ ten temat szerzej zob. D. Smith, Skazani. Ostatnie dni rosyjskiej arystokracji, Kraków 2014, s. 60-61, 65, 125, 206, 215, 225. Echa wydarzeń związanych z rewolucją, wojną domową i koniecznością opuszczenia Rosji obecne są w pamiętnikach Władimira i Nikołaja Nabokowów: V. Nabokov, op. cit., passim; N. Nabokov, Bagazh. Memoirs of a Russian Cosmopolitan, New York 1975, passim.

${ }^{122}$ V. Giroud, op. cit., s. 24 i n.

123 W. Jędrzejewicz, Wspomnienia, oprac. i posłowiem opatrzył J. Cisek, WrocławWarszawa-Kraków 1993, s. 9.

124 W. Pobóg-Malinowski, W. Jędrzejewicz, Listy 1945-1962, oprac. S.M. Nowinowski, R. Stobiecki, Warszawa 2016, s. 308 (list W. Jędrzejewicza do W. PobógMalinowskiego, 25 czerwca 1948). 
rzem powiatu miechowskiego oraz szpitala w Miechowie, a nadto gorliwym stronnikiem insurekcji i zażartym wrogiem carskiej Rosji ${ }^{125}$.

Tym samym historia zatoczyła swoistego rodzaju krąg, mimochodem splatając życie ludzi przebywających na innym kontynencie i może nawet nieświadomych, jak wiele ich łączy we wspólnej niełatwej przeszłości. Cały nasz wywód to dowód na swoiście rozumianą przewagę mikrohistorii jako zjawiska bardziej trwałego, bo i bardziej przyziemnego, a przez to łatwiej uchwytnego, nad makrohistorią, wszakże mniej odporną na szybciej zmieniające się koniunktury o globalnym zasięgu w rozpędzonym biegu dziejów. Poruszone przez nas drobne epizody o lokalnym wymiarze, innymi słowy to, co Francuzi zwykli nazywać „małą historią” (petite histoire), wkomponowane w wielkie wydarzenia (grande histoire) niczym soczewka przybliżają cały zawiły splot relacji polsko-rosyjskich w początkach wielkiej wojny, oddając odarty z mitów oraz legend tragizm losów Polaków i Rosjan powiązanych trudnymi do rozerwania węzłami przeszłości.

125 E. Klimczyk, „Po pierwsze nie szkodzić” czyli historia Józefa Buchnera, który miechowian leczyt... Codzienność z przesztości, „Wieści Miechowskie”, 26 maja 2017, nr 10 (402), s. 11. 